\title{
A GLOBAL SYSTEMATIC REVIEW ON ORCHID DATA IN PROTECTED AREAS
}

\author{
Anatoliy A. Khapugin ${ }^{1,2}$ \\ ${ }^{1}$ Joint Directorate of the Mordovia State Nature Reserve and National Park «Smolny», Russia \\ ${ }^{2}$ Tyumen State University, Russia \\ e-mail: hapugin88@yandex.ru
}

Received: 30.12.2019. Revised: 27.02.2020. Accepted: 16.04.2020.

\begin{abstract}
A systematic global literature review of studies devoted to Orchidaceae taxa in Protected Areas is presented here. It is aimed to understand research topics of studies on orchids in Protected Areas around the world. Used is the methodology well established in biological and medical science with a focus on two international databases (Scopus, Web of Science Core Collection) and one national (Russian Science Citation Index). Examined are the data on each paper's Protected Area location, habitat studied, topic discussed, and IUCN status of each Protected Area. It is hypothesised that orchids are predominantly investigated in Protected Areas, and therefore, the published results of studies on orchids are properly indexed by databases globally. The question is whether the most threatened plants, orchids, would be investigated in more detail and intensity in areas legally protected by authorities (nature reserves, national parks, natural monuments, wildlife sanctuaries, etc.), and whether the databases Scopus, Web of Science Core Collection, Russian Science Citation Index cover appropriately the majority of papers on orchids in Protected Areas on a global scale. There were found 331 publications on orchids in Protected Areas, including 72 from RSCI, 96 from Scopus, 163 from Web of Science Core Collection. A high percentage of the studies were conducted in the tropics, while vast temperate and subtropical regions (Northern Eurasia, Central and Western Asia, Northern and Central parts of North America, non-tropical Africa, and most parts of Australia) were poorly represented. Most studies were conducted in forests (in descending order of abundance - tropical, temperate, boreal), and were focused predominantly on the diversity and distribution of orchids in Protected Areas, followed by issues of taxonomy, structure and population dynamics, conservation threats of Orchidaceae, and orchid-consort interactions (insects-pollinators, trees-phorophytes, symbiotic fungi). It is concluded that the use of only the databases Scopus, Web of Science Core Collection and Russian Science Citation Index does not provide a sufficient amount of data to generalise comprehensive data about studies of orchids in Protected Areas at a global scale. In future systematic reviews of other, in non-English-language, international and national databases should be carried out.
\end{abstract}

Key words: bibliographic database, biodiversity, conservation, focus of study, habitat, national park, nature reserve, Orchidaceae, threatened taxa

\section{Introduction}

With over 28000 accepted species within 763 genera (Christenhusz \& Byng, 2016), the Orchidaceae is one of the richest plant families in the world. Orchids are distributed over all the continents except Antarctica, with the greatest abundance in tropical and subtropical regions (Chase, 2005). Orchids occupy a wide range of habitats, with epiphytic, terrestrial, and subterranean life forms (Cribb et al., 2003; Givnish et al., 2016). Despite this, many orchids are endemic to small areas, naturally rare and threatened (e.g. Waterman \& Bidartondo, 2008; Crain \& Tremblay, 2014; Barberena et al., 2018; Fateryga et al., 2020). More than half (56.5\%) of the 948 orchid species estimated worldwide using Global IUCN Red List criteria were considered threatened (e.g. Gale et al., 2018). Apart of global IUCN estimation, there are numerous publications concerning regional assessment of orchid species using IUCN Categories and Criteria (e.g. Blinova \& Uotila, 2011; Eliáš et al., 2015; Khapugin et al., 2017a,b; Zhou et al., 2018). Such assessments provide up- dates for orchid species' status in different regions and contribute to gathering and providing newer data for global IUCN estimation of certain taxa. Taxa within the Orchidaceae are still being described annually in the tropics and subtropics (e.g. Forster \& Souza, 2007; Averyanov et al., 2016a, 2018; Ječmenica et al., 2016; Pelser et al., 2016) and less commonly in temperate regions (e.g. Jagiełło, 1988). A high percentage of endemism is noticed within this plant family (Hopper \& Gioia, 2004; Swarts \& Dixon, 2009). Specifically, orchid richness and abundance depends on habitat size, elevation range (Jacquemyn et al., 2005; Schödelbauerová et al., 2009; Acharya et al., 2011; Crain \& Tremblay, 2014), light availability, soil moisture, and canopy height and area (Gravendeel et al., 2004; Huang et al., 2008; McCormick \& Jacquemyn, 2014). As the largest and most threatened family (Chase, 2005; Crain \& Tremblay, 2014; Christenhusz \& Byng, 2016; Barberena et al., 2018; Efimov, 2020), the Orchidaceae is a flagship plant family for conservationists, biologists and ecologists worldwide (Fig. 1). 

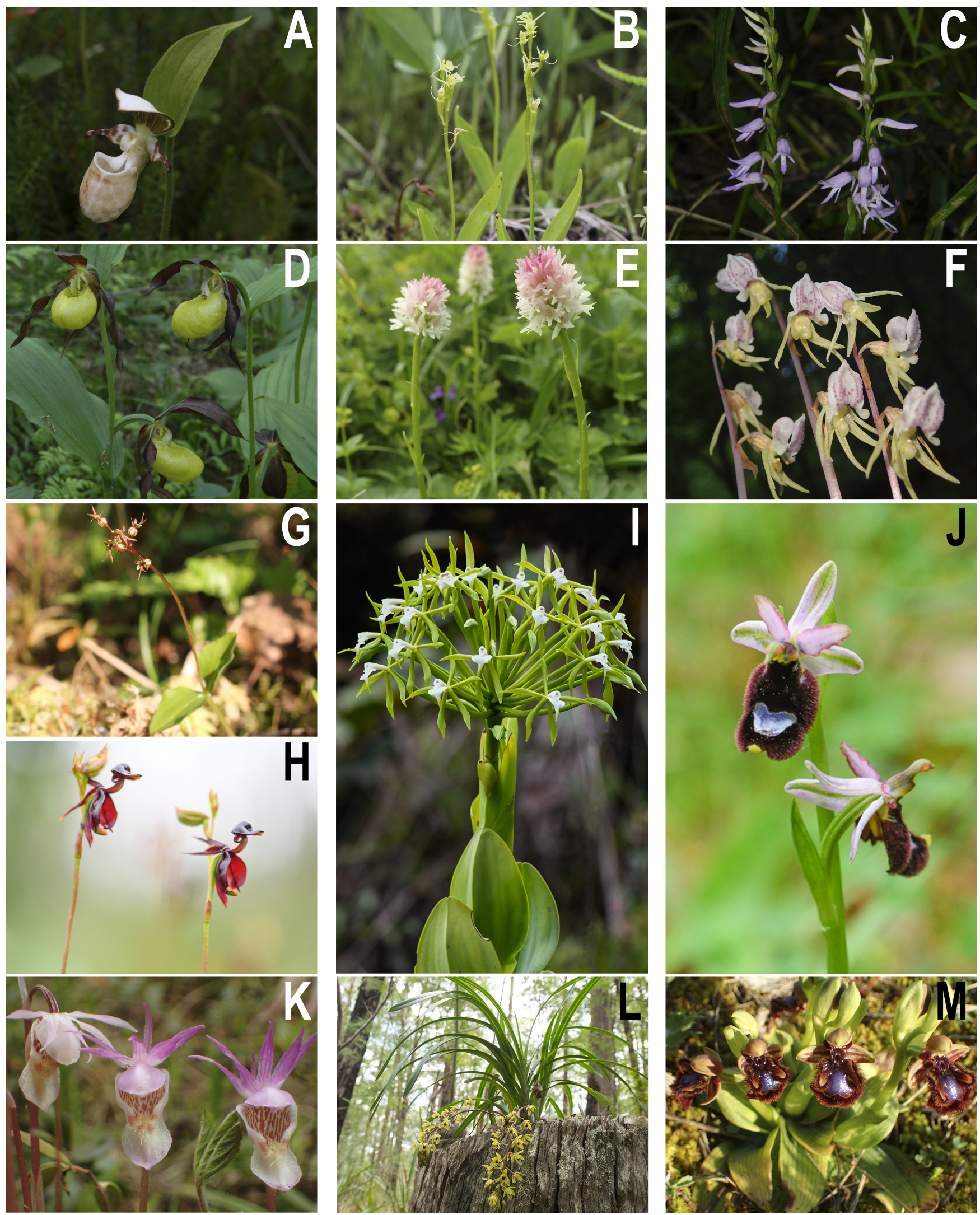

Fig. 1. Orchids in Protected Areas. A - Cypripedium yatabeanum in the Nalychevskiy National Park, Russia (P.G. Efimov); B - Liparis loeselii in the Sebezhskiy National Park, Russia (P.G. Efimov); C - Ponerorchis cucullata in the National Park «Smolny», Russia (A.A. Khapugin); D - Cypripedium calceolus in the Mordovia State Nature Reserve, Russia (A.A. Khapugin); E - Nigritella carpatica in the Verkhovyna National Nature Park, Ukraine (M. Bobocea); F - Epipogium aphyllum in the Bucegi Natural Park, Romania (M. Bobocea); G - Neottia cordata in the Vodlozerskiy National Park, Russia) (G.G. Chugunov); H - Caleana major in the Grantville Nature Reserve, Australia (W. Chen); I - Epidendrum lacustre in the Alto Mayo Protection Forest, Peru (W. Chen); J - Ophrys flavicans in the Gargano National Park, Italy (W. Chen); K - Calypso bulbosa in the Oulanka National Park, Finland (M. Bobocea); L-Cymbidium suave in the Ku-ring-gai Chase National Park, Australia (W. Chen); M - Ophrys speculum subsp. speculum in the Mount Olympus National Park, Greece (M. Bobocea). 
There are now over 100000 Protected Areas (PAs) worldwide, covering over $12 \%$ of the Earth's land surface (Chape et al., 2005; PARF, 2019; UNEP-WCMC \& IUCN, 2019). Protected Areas are a key component of the global response to environmental changes and degradation (Gaston et al., 2008; Conroy et al., 2011). They positively contribute to biodiversity conservation (Leverington et al., 2010; Akasaka et al., 2017; Ruchin \& Makarkin, 2017; Gebremedihin et al., 2018). The effectiveness of Protected Area Networks in different regions depends on representativeness of endemic and threatened taxa (Jackson et al., 2009; Vellak et al., 2009; Gray et al., 2016), size (Schödelbauerová et al., 2009; Leroux et al., 2015), type (Lemenager et al., 2014; Fitzsimons, 2015; Furlonge et al., 2015), and protection support on behalf of government and non-government authorities (Jackson \& Gaston, 2008; Leverington et al., 2010; Tuvi et al., 2011; Bicknell et al., 2017). It is well-known that in several parts of the world, biological diversity generally decreases (Butchart et al., 2010; Le Roux et al., 2019), even within established PAs (Clark et al., 2013; Hill et al., 2015). Protected Areas are considered the most effective effort to protect characteristic or threatened species, habitats and ecosystems and to counteract the biodiversity loss (Geldmann et al., 2013; Coetzee et al., 2014; Gray et al., 2016). Obviously, PAs attract researchers of different scopes as a platform for studying a target object within minimally disturbed ecosystems. Hence, it can be assumed that most threatened plants (orchids) would be investigated in more detail and intensity in areas legally protected by local or federal authorities (nature reserves, national parks, sanctuaries, etc.). It is hypothesised that orchids are likely to be investigated in PAs and publications on the Orchidaceae family are better indexed by databases in the most orchid-rich regions more than in regions poor in orchid species.

Conducted is a systematic review using literature indexing tools in three databases (two international and one national (Russian)) to identify areas that have received less attention in research of orchids for promoting more intense studies in future. The aims are to: (1) qualitatively summarise the literature on studies of orchids including publication information, study area location, ecosystem/ habitat investigated, problem/topic discussed, IUCN status of PAs; and (2) summarise the data on PAs distribution where orchids are investigated using data from selected databases.

\section{Material and Methods}

Generated is a literature search for orchid species using three databases (Fig. 2): Web of Science Core Collection (WoS CC), an international database; Scopus, an international database; Russian Science Citation Index (RSCI) database, a Russian database.

In WoS CC, were used the following search strings on 23 December 2019 to obtain studies on Orchidaceae in PAs: Topic: [(Orchid*) AND («Protected Area*» OR «Reserve» OR «National Park» OR «Sanctuary» OR «Natural Monument» OR «Natural Park»)]. Subsequently is used the default search engine settings for the Science Citation Index Expanded (1975-2019) but excluded the Social Sciences and Arts \& Humanities citation indices. Finally, records were refined by document types: Article OR Review.

As an international alternative is used the search function in the database Scopus. Although the search and exclusion options are not identical between the two databases, the same search terms were used, on 23 December 2019. Like WoS CC, the search was delimited by relevant areas of study by using the «Limit to» function to include studies in the following areas: Agricultural and Biological Sciences OR Environmental Science OR Biochemistry, Genetics and Molecular Biology OR Earth and Planetary Sciences. Subsequently the results were narrowed to a subset of studies published in «Journal» source type. When found the same study in WoS CC and Scopus, it was attributed to WoS CC.

In the RSCI database, literature was searched on 23 December 2019, using the following search strings: Topic: [(orkhid*) AND (orchid*)]. Both Russian and English characters were used for the input of the searching terms in RSCI. Then the search was delimited by relevant areas of study by using the "Thematic» function to include studies in the following areas: «Botany» OR «Ecology» OR «Theory and Methods of Environment Research and Conservation. Environmental Basis of Use of Natural Sources» OR «Plant and Animal World Conservation» OR «Wildness Conservation. Terrestrial and Aquatic Protected Areas» OR «Conservation of Environment and Natural Sources in Separate Regions and Countries».

Non-related publications were excluded by title, abstract and/or a careful reading of full text if necessary. Only included is literature that reported on orchid species in PAs or on non-field-based studies of orchids collected in PAs, including laboratory, genetic and cytological studies, and rarer reviews of generalised data on orchid species in PAs. 


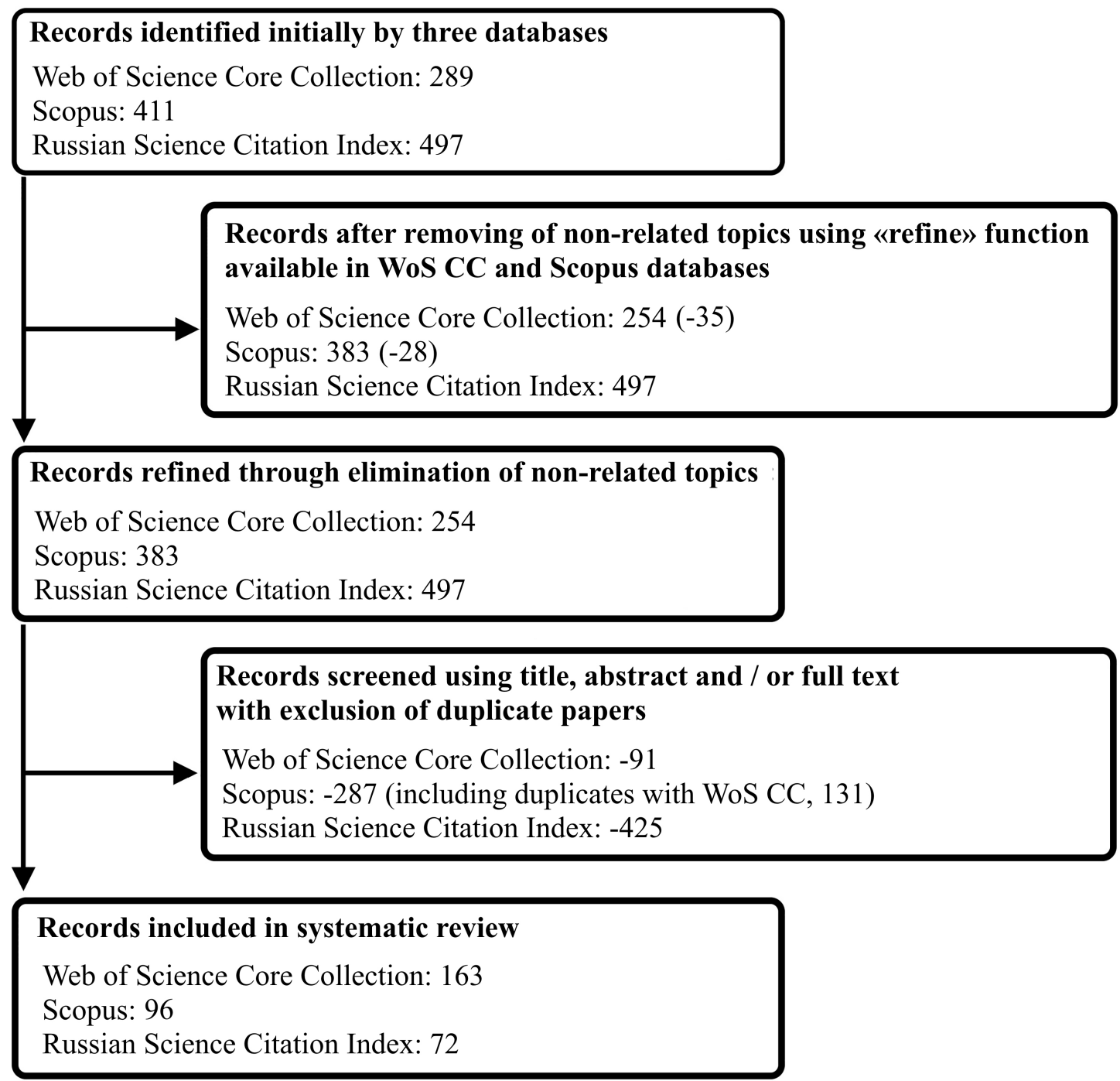

Fig. 2. Diagram documenting search and inclusion process and criteria.

According to these requirements, initially 1197 records were identified across the three databases accessed, of which 497 were from RSCI, 289 - from WoS CC, 411 - from Scopus. After refining (available only in WoS CC and Scopus), the records were reduced to 254 and 383, respectively. Excluded were 865 studies on unrelated topics (of which 425 were from RSCI, 287 - from Scopus, 91 - from WoS CC), or duplicates after reading abstracts or full texts (if needed). Eventually, 331 papers were included according to the criteria, of which 72 were from RSCI, 96 - from Scopus, 163 - from WoS CC (Fig. 2 and see Electronic Supplement 1). There were overlaps (all of which were assigned to WoS CC) of 131 records between Scopus and WoS CC, five records between RSCI and WoS CC.

Then the following information was extracted from all remaining studies: (1) publication journal; (2) year of publication; (3) country in which the study was conducted; (4) list of PAs in each coun- try; (5) co-ordinates of study location; (6) habitat in which the species of interest were found; (7) focus of the study (see below).

Distinguished are nine types of habitats where orchids have been studied: (1) Tropical forests; (2) Temperate forests; (3) Boreal forests; (4) Shrublands/scrublands; (5) Grasslands; (6) Farmlands; (7) Peatlands; (8) Cliffs and rocks.

The studies included in our review are classified into seven focal categories: (1) Plant-consort interaction; (2) Conservation threats; (3) Orchids as source for laboratory studies; (4) Population structure and dynamics; (5) Distribution and diversity; (6) Taxonomic studies; (7) Economic importance and uses.

Google Maps (https://www.google.com/maps) has been used to indicate the location of PAs according to their latitude and longitude. When study sites were identified by more than one location within a PA, each of them has been characterised by their mid-point, using the Geographic 
Midpoint Calculator (http://www.geomidpoint. com). On the basis of co-ordinates, all PAs have been separated in natural zones: tropics (between $23.5^{\circ} \mathrm{N}$ and $\left.23.5^{\circ} \mathrm{S}\right)$, subtropics $\left(23.5^{\circ}-35.0^{\circ} \mathrm{N}\right.$ and $\left.23.5^{\circ}-35.0^{\circ} \mathrm{S}\right)$, temperate zone $\left(35.0^{\circ}-66.5^{\circ} \mathrm{N}\right.$ and $\left.35.0^{\circ}-66.5^{\circ} \mathrm{S}\right)$, Arctic $\left(66.5^{\circ}-90.0^{\circ} \mathrm{N}\right)$ and Antarctic $\left(66.5^{\circ}-90.0^{\circ} \mathrm{S}\right)$.

In addition, the 2018 bibliometric data have been compared on the included journals from Scopus and WoS CC. For this purpose, analysed are the 2018 JCR Impact Factor (IF) of journals from WoS CC and the 2018 CiteScore values of journals from Scopus (available at http://www.scopus. $\mathrm{com} /$ ). Finally all journals are ranked by quartiles of both databases to demonstrate the quality of journals dealing with orchid research in PAs.

\section{Results}

\section{Journals and years of publication}

The 331 involved studies on orchids in PAs were published in 155 different journals. Of these 155 journals, 46 ones were identified by RSCI with 72 articles, 60 - by Scopus with 96 articles, and 80 - by WoS CC with 163 articles (Fig. 3).

The publications on orchids in PAs in the selected databases included in the review were published from 1969 to 2018 (Fig. 4). A remarkable increase in number of published studies occurred in the 2000s with a few peaks (2007, 2011, and 2017) and declines (2006, 2010, and 2012). Noticed is a higher contribution of publications by WoS CC and Scopus databases through the study period. The RSCI database has contributed considerably to the number of published articles since 2000.

The 2018 JCR IF was available for 96 of the 107 journals included in the analysis. The highest number of articles has been published in journals devoted mainly to plant systematics (Phytotaxa, Lankesteriana, etc.) or, less commonly, to plant conservation (Biodiversity and Conservation, Biological Conservation) (Table). Four journals (International Journal of Environmental Studies, Canadian Field Naturalist, Genetics and Molecular Research, and Acta Universitatis Agriculturae et Silviculturae Mendelianae Brunensis) did not have a 2018 JCR IF due to indexation discontinuing in 1985, 2011, 2015, and 2017 respectively). Five journals (Acta Agrobotanica, Biosystems Diversity, Nature Conservation Research, Revista de Sociedad Gaditana de Historia Natural, Tomsk State University Journal) were excluded from this analysis as the sources are indexed in Emerging
Sources Citation Index database. In general, the 2018 IF JCR of all included journals varied between 0.283 (Acta Biologica Colombiana) and 7.299 (New Phytologist).

Of the 127 Scopus titles, seven journals (Indian Forester, Zoos' Print Journal, Revista Cientifica UDO Agricola, Asian Journal of Plant Pathology, Svensk Botanisk Tidskrift, Fragmenta Floristica et Geobotanica Polonica, and Bangladesh Journal of Plant Taxonomy) were excluded from this analysis as discontinued in the database after 2001, 2008, 2012, 2016, 2017, 2018, and 2018 , respectively. Among the analysed journals, the 2018 CiteScore values varied between 0.000 (Ecologia Balkanica and Acta Botanica Venezuelica) and 3.787 (New Phytologist). No relationship between number of articles per journal and IF JCR / CiteScore values $(p>0.05)$ could be found. This indicates the significance of different-level journals in highlighting the research of orchids in PAs in worldwide (Fig. 5).

\section{Location of Protected Areas, habitats and} study focuses

Based on analysis of records included, the studies of Orchidaceae species in PAs were carried out in eight habitats as reported in 283 papers, while 49 papers did not provide any information on habitat. Habitats investigated included tropical forests, temperate forests, boreal forests, shrublands and scrublands, grasslands, farmlands, peatlands, and cliffs and rocky sites (Fig. 6). The largest number (228) of studies across all databases on orchids in PAs was in forest ecosystems with a predominance in the tropics. Lower numbers of studies were conducted in grasslands (77), followed by peatlands (20), farmlands (16), shrublands \& scrublands (14), on cliffs \& rocks (12) (Fig. 6).

The most common focus of the studies on Orchidaceae in PAs concerned issues of diversity and distribution of plant species around the world. Taxonomic studies were also abundant in the analysis, followed by studies on structure and dynamics of populations, conservation threats, and interactions of orchids with their consorts (insects-pollinators, trees-phorophytes, symbiotic fungi) (Fig. 7). Orchid species used as sources for laboratory studies (morphology, anatomy, genetics, phylogeny, in vitro propagation, seed germination, fungal diversity in orchid roots) were found in 29 publications. Many publications were devoted to both diversity and taxonomy of orchids. 


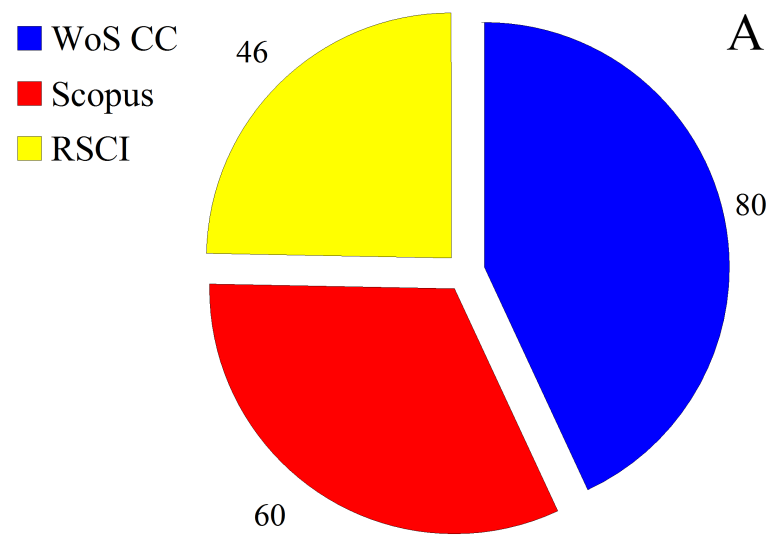

A

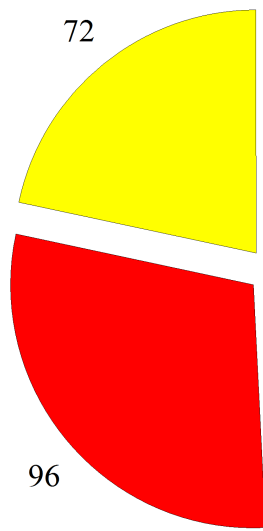

B

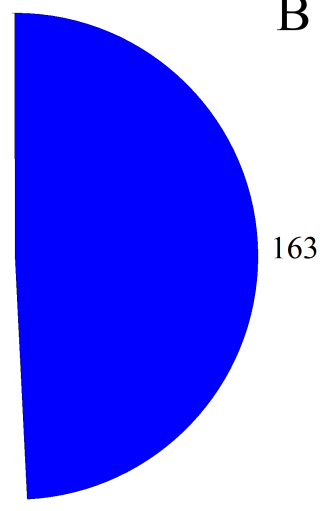

Fig. 3. The number of journals (A) and publications (B) identified through a global literature search from 1975 to December 2019 using RSCI, WoS CC, and Scopus databases for research on orchids in Protected Areas.

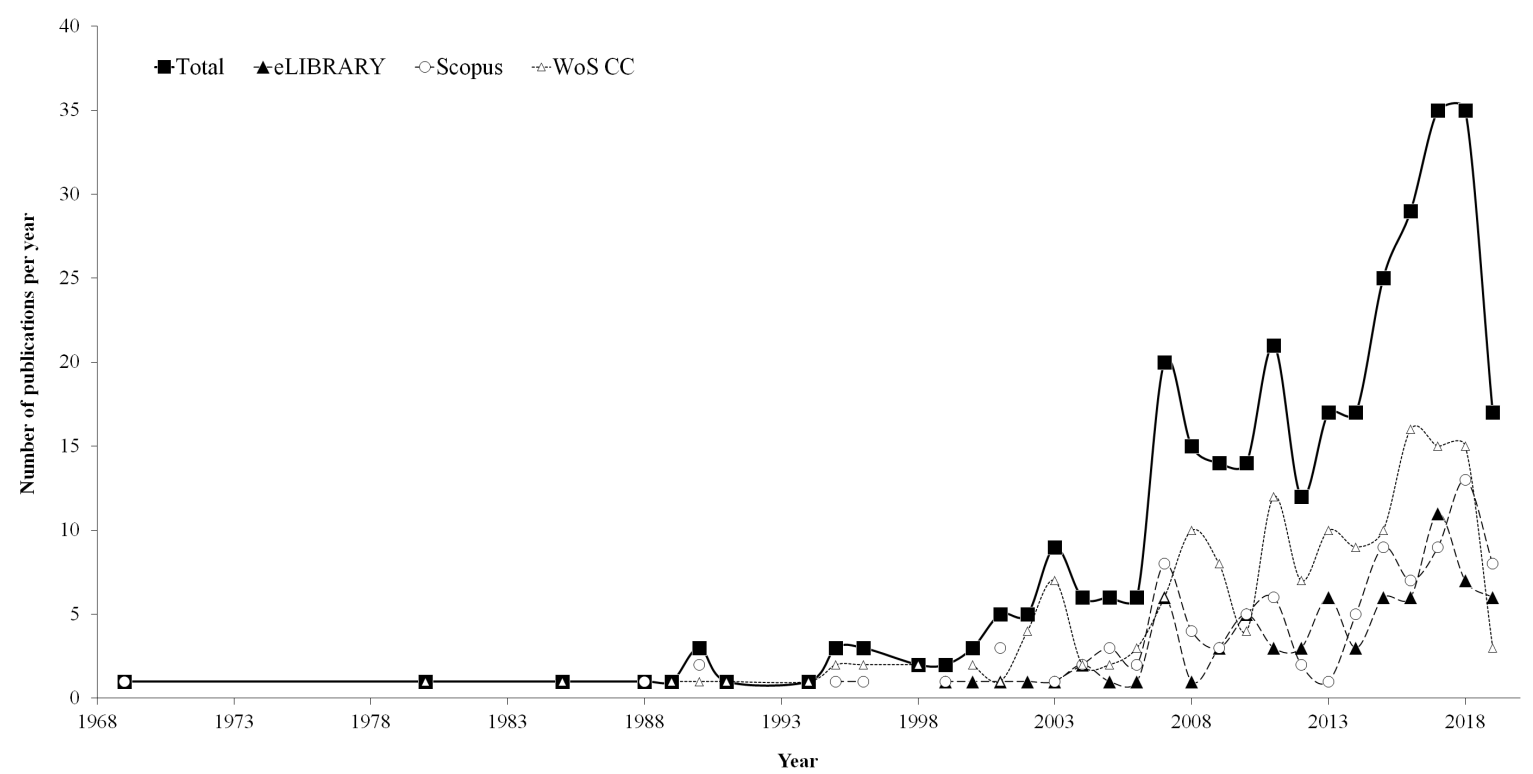

Fig. 4. The number of publications per year. Global literature identified through a search from 1975 to December 2019 using RSCI, WoS CC, and Scopus databases for research on orchids in Protected Areas.

Table. The list of leading journals in terms of number of articles included in the review.

\begin{tabular}{lccc}
\hline Journal & $\begin{array}{c}\text { Quartile } \\
\text { CiteScore / JCR }\end{array}$ & $\begin{array}{c}\text { Number of } \\
\text { articles }\end{array}$ & $\begin{array}{c}\text { Percent of total } \\
\text { number of articles }\end{array}$ \\
\hline Phytotaxa & Q3 / Q3 & 20 & 6.5 \\
Lankesteriana & Q3 / & 14 & 4.2 \\
Turczaninowia & Q3 / & 11 & 3.6 \\
Botanical Journal of the Linnean Society & Q1 / Q1 & 10 & 3.2 \\
Biological Conservation & Q1 / Q1 & 9 & 2.9 \\
Taiwania & Q3 / Q4 & 9 & 2.9 \\
Biodiversity and Conservation & Q1 / Q1 & 7 & 2.3 \\
PhytoKeys & Q2 / Q2 & 7 & 2.3 \\
Fragmenta Floristica et Geobotanica Polonica & $-/-$ & 6 & 1.9 \\
Biotropica & Q1 / Q2 & 5 & 1.6 \\
Botanical Sciences & Q3 / Q3 & 5 & 1.6 \\
Herald of Tver State University. Series: Biology and Ecology & $-/-$ & 5 \\
Acta Botanica Brasilica & Q2 / Q3 & 5 & 1.6 \\
Australian Journal of Botany & Q2 / Q3 & 4 & 1.3 \\
Plant Biology & Q1 / Q2 & 4 & 1.3 \\
Plant Ecology and Evolution & Q3 / Q3 & 4 & 1.3 \\
Plant Systematics and Evolution & Q2 / Q2 & 4 & 1.3 \\
Others & & 179 & 57.9
\end{tabular}




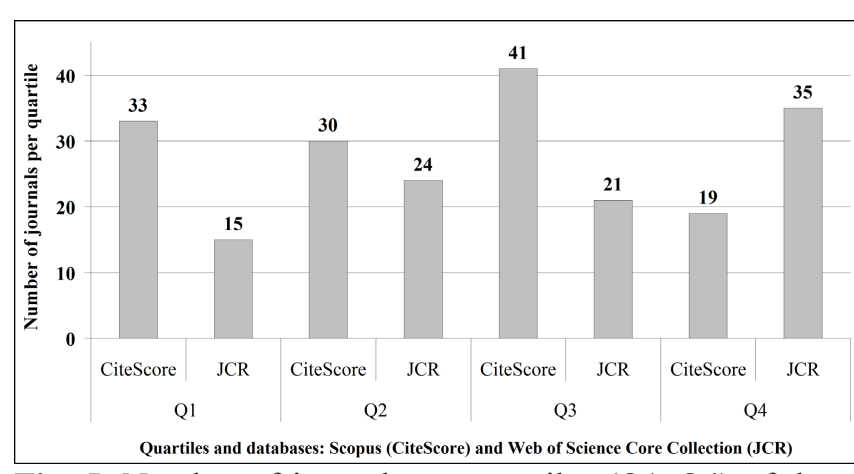

Fig. 5. Number of journals per quartiles (Q1-Q4) of databases Scopus (2018 CiteScore), and Web of Science Core Collection (2018 JCR IF) analysed.

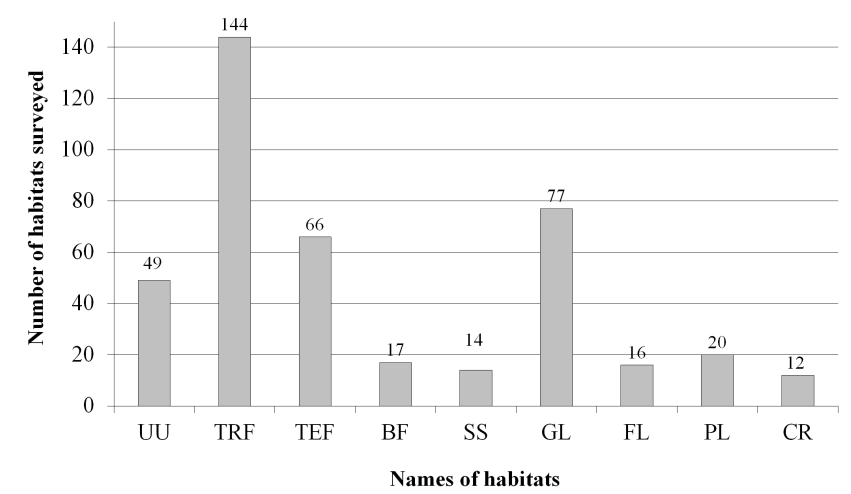

Fig. 6. Habitats investigated (Plots include studies from Web of Science Core Collection, Scopus, and RSCI). Habitat designations: UU - Unknown / Uncertain, TRF - Tropical Forest, TEF - Temperate Forest, BF - Boreal Forest, SS Shrubland and Scrubland, GL - Grassland, FL - Farmland, PL - Peatland, CR - Cliffs and Rocks.

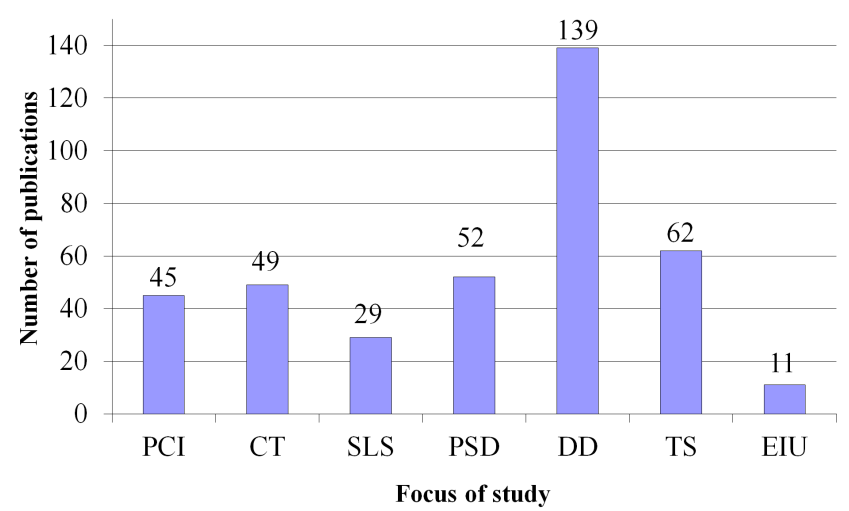

Fig. 7. Focus of study (Plots include studies from Web of Science Core Collection, Scopus, and RSCI). Names of focuses: PCI - Plant-consort(s) interactions, CT - Conservation threats, SLS - Source for laboratory studies, PSD - Population structure and dynamics, DD - Distribution and diversity, TS - Taxonomic studies, EIU - Economic importance and uses.

There are 376 PAs in which Orchidaceae species have been studied, or from where plant material has been extracted for laboratory investigations (Fig. 8, and see Electronic Supplement 2). Geographically, 47 PAs are located in nine countries of South America (12.7\% of all countries and $12.5 \%$ of all PAs); 61 PAs - in ten countries of North America (14.1\% of all countries and $16.2 \%$ of all PAs); 109 PAs - in 19 countries of Asia (26.8\% of all countries and $29.0 \%$ of all PAs); 131 PAs - in 21 countries of Europe $(29.6 \%$ of all countries and $34.8 \%$ of all PAs); 11 PAs - in two countries of Oceania $(2.8 \%$ of all countries and $2.9 \%$ of all PAs) $; 17$ PAs - in 10 countries of Africa $(14.1 \%$ of all countries and $4.5 \%$ of all PAs) (Fig. 8).

The 376 PAs were classified into six IUCN protected area management categories (Dudley, 2008). Only 54\% (categories Ia, Ib, II - Fig. 9) of all PAs have a special protection regime supported by a Guard Department staff of nature reserves and national parks. We believe orchid populations are comprehensively protected only under these conditions. At the same time, PAs of other categories (III, IV, V, VI) are exposed to human influence on a different level. As one of the most vulnerable plant families, the surviving of orchids could be possible only under minimal human pressure or under accurate management of orchid habitats in urbanised and/or populated areas.

On the basis on data on location of PAs, all study sites are assessed to four climate zones, arctic, temperate, tropics, subtropics, to determine, which regions present the highest number of PAs with orchid research. The survey demonstrates that selected bibliographic databases confirm the predominance of tropical and temperate PAs for investigation on Orchidaceae species (Fig. 10, Electronic Supplement 2). A lower number (42) of PAs were located in the subtropics, while only two PAs (Malla Strict Nature Reserve, Finland; Kandalaksha State Nature Reserve, Russia) were identified as Arctic.

\section{Discussion}

This systematic review documents the evidence of studies on Orchidaceae within PAs around a world. Undoubtedly, this undercounts areas where the species are presented, because the analysed international (WoS CC, Scopus) and regional (RSCI) databases do not include all studies. Therefore, a systematic review carried out using national and regional literature databases may offer more comprehensive insights into the general literature on studies of orchids in PAs around a world. 


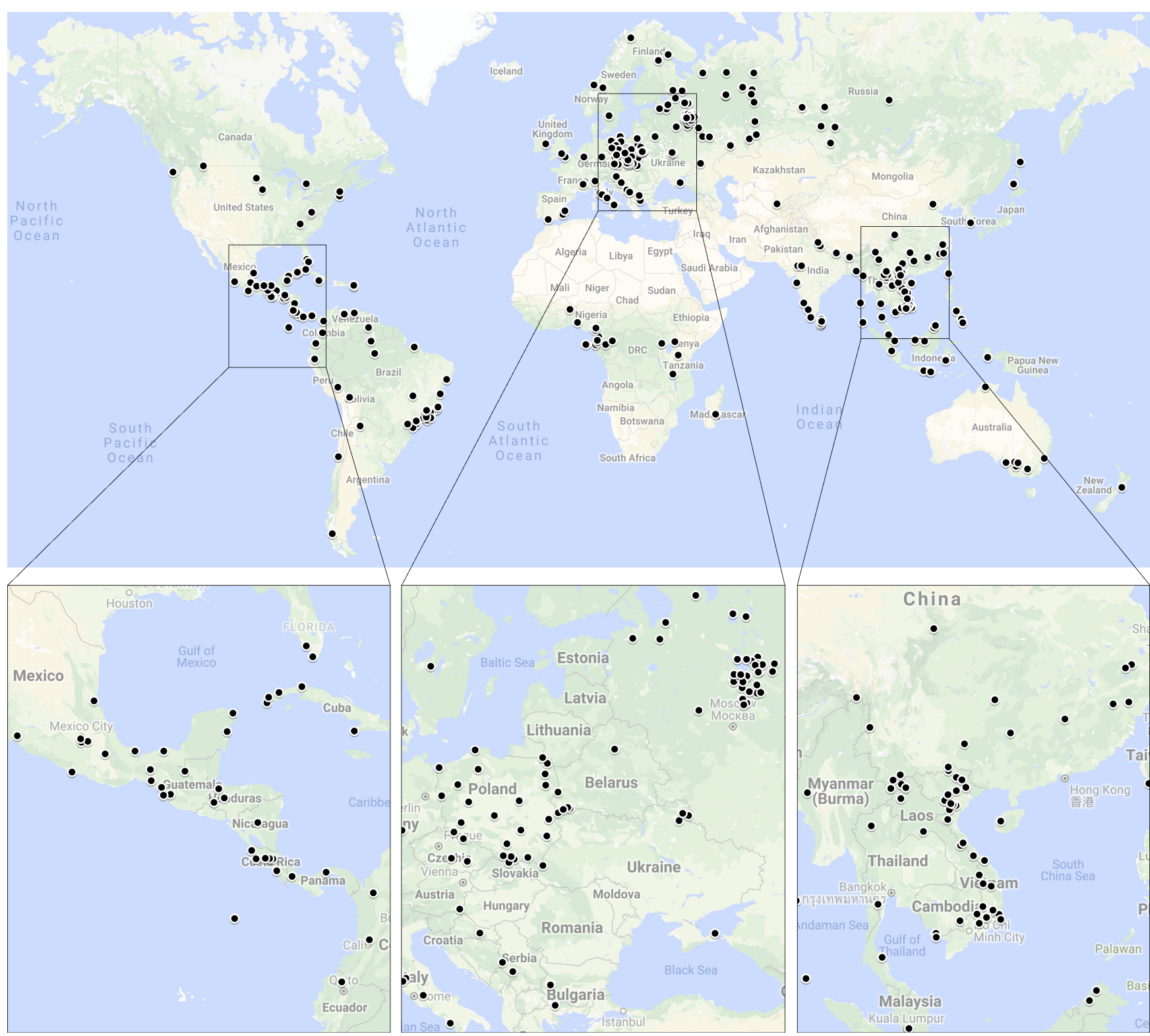

Fig. 8. Location of Protected Areas in examined papers.

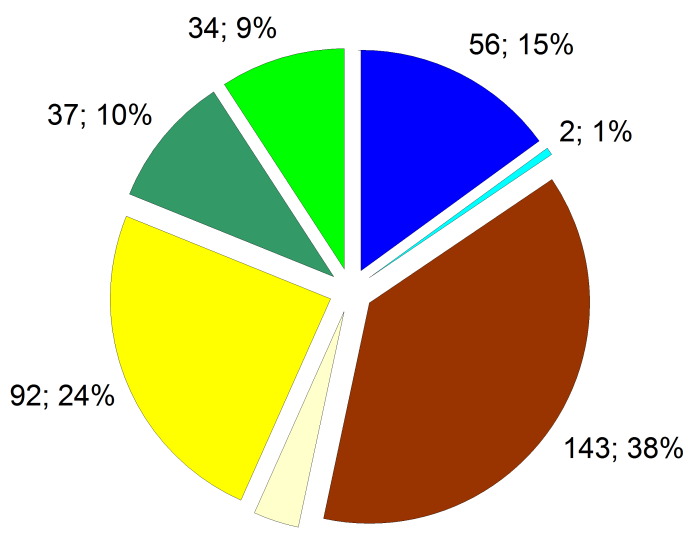

$12 ; 3 \%$

口la $\quad$ lb $\quad$ II $\quad \square$ III $\square$ IV $\quad \square$ V $\quad \square$ VI

Fig. 9. Proportion of different IUCN categories of Protected Areas in included papers. Designations: Ia - Strict Nature Reserve; Ib - Wilderness Area; II - National Park; III - Natural Monument or Feature; IV - Habitat/Species Management Area; V - Protected Landscape/ Seascape; VI - Protected area with sustainable use of natural resources.

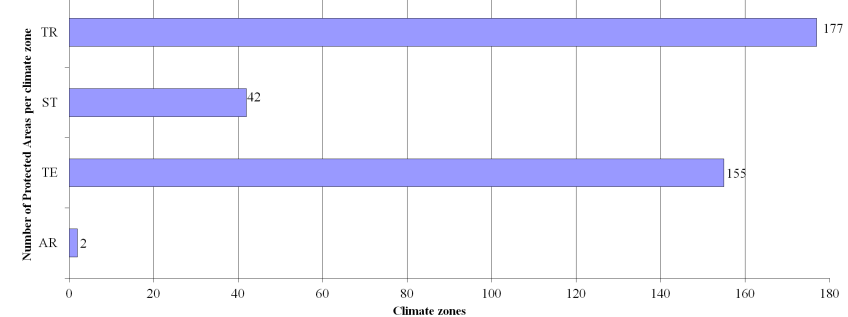

Fig. 10. Number of Protected Areas per climate zone (Plots include studies from Web of Science Core Collection, Scopus, and RSCI). Climate zone designations: AR - arctic zone, TE - temperate zone, ST - subtropics, TR - tropics.

Research on orchids in PAs increased since 2000s in all analysed databases (Fig. 4). This is not caused by an increase in data on Orchidaceae in PAs since this time. The main reason is the beginning of database processing - 1997 (WoS CC), 1998 (RSCI), 2004 (Scopus). Similar results from different published global systematic reviews 
(e.g. Lowry et al., 2013; Davis et al., 2016; Galvin et al., 2018; Jones \& Daehler, 2018; Chichorro et al., 2019) based on international and regional bibliographic databases confirm this assumption.

A large proportion of studies included in this systematic review for orchids in PAs was conducted in areas located mainly in Southeast Asia and Central America, followed by Central and Eastern Europe (Fig. 5). At the same time, several regions were identified with a lack (Northern and Middle Asia, Africa, northern and central parts of North America, Australia) or absence (West Asia) of data. In these regions can be noted botanists working on orchids. For instance, Reiter et al. (2013) and Indsto et al. (2006) in Australia, there are two scientific teams in Africa, including Bulafu et al. (2007), Mucunguzi (2007) in the first team, and Descourvières et al. (2013), Droissart et al. (2014), Ječmenica et al. (2016, 2017), Simo-Droissart et al. (2018) in the second one. The North American authors' group is represented by publication of Dutra et al. (2009), Gutting et al. (2015), Mújica et al. (2018). Only one study (Beshko et al., 2017) was found in Central Asia. Taking into account the high vulnerability of orchids around the world, it is assumed that studies of orchids are obviously being conducted in a wider range, but their results have not been published in the databases WoS CC, Scopus and RSCI. For example, such studies are represented by unpublished manuscripts, reports, etc. or they are published in journals (e.g. Dey et al., 2007; Khapugin \& Korochkina, 2017), at a conference proceedings (e.g. Gale et al., 2013; Hervouet \& Misandeau, 2018), numerous «grey» literature, and books (e.g. Vakhrameeva et al., 2014; Tsiftsis \& Tsiripidis, 2015; Kreutz et al., 2018) which were not indexed neither in international, nor in regional bibliographic databases. It makes the search and generalisation of data on orchid biology, ecology and conservation incomplete. Hence, even involvement of all known bibliographic databases cannot provide complete data on orchids in PAs. The handle search of literature apart from bibliographic databases could yield the most comprehensive results, but that is rather time consuming.

In the selected databases, a large number of studies on orchids in PAs has been conducted in forests and grasslands with considerable dominance of the first habitat type. Other authors have demonstrated a higher confinement of orchids to forest habitats, too (e.g. Wraith \& Pickering,
2017). Noteworthy, studies of orchids in PAs in different forest types have demonstrated the highest orchid abundance in tropical forests with a declining from equator to the poles. This picture is similar to the distribution of PAs, which have the highest abundance in the tropics (Fig. 10). Previous studies have demonstrated that orchid diversity hotspots occur in areas of high diversity of plants (Myers et al., 2000; Cribb et al., 2003; Zhang et al., 2015). However, noticeable is a high abundance of analysed PAs in Europe (Fig. 8). This could be explained by a more comprehensive character of investigations in this region. For instance, some publications in this review are devoted to three and more PAs (e.g. Stefaniak et al., 2013; Koval et al., 2018).

Concerning the study focus, papers indexed in different bibliographic databases have not been analysed separately. Overall, the study has focused first of all on the diversity and distribution of orchid species in PAs. This was expected as the Orchidaceae is one of the richest and diverse plant families. Noteworthy, studies conducted in temperate regions have concerned only orchid diversity and distribution, i.e. they represented statements or confirmations of the orchid species presence in PAs (e.g. Stefaniak et al., 2013; Serra Laliga et al., 2015; Koval et al., 2018). At the same time, in tropics and subtropics, studies on Orchidaceae included also additional data on the plant taxonomy (e.g. Averyanov, 2012; Averyanov et al., 2016a,b), economic value (e.g. Cerda et al., 2013; Liu H. et al., 2014), and conservation threats (e.g. Sinu et al., 2011; Raventós et al., 2015). The studies on orchid taxonomy ranked a second place among study focuses due to permanently newly described taxa of this plant family (e.g. Averyanov, 2012; Descourvières et al., 2013; Ječmenica et al., 2017; Zhou et al., 2018). The results expectedly demonstrated that these studies concerned orchid diversity hotspots - tropics and subtopics. Although there is a lower number of studies devoted to orchid populations and conservation threats, these results are the most important for the knowledge on Orchidaceae species due to the global increase in habitat degradation and destruction, climate change, livestock grazing (e.g. see Soto Arenas et al., 2007; Liu H. et al., 2010; Liu Q. et al., 2015; Kull et al., 2016; Le Roux et al., 2019). The highest number of population-based studies has been concerned investigations of 1-2 orchid species (e.g. Raventós et al., 2015; Khapugin et al., 2016, 2017a; Br- 
zosko et al., 2017; Puchnina, 2017; Kirillova \& Kirillov, 2020). However, there are a few studies (Pierce et al., 2006; Stefaniak et al., 2013; Talalaj et al., 2017) concerning a higher number of orchid species which are more valuable for further comparison. Finally, the lowest number of studies on orchids in PAs was devoted to economic importance and use of orchids. They predominantly concerned South Asian (Samant et al., 1998) and East Asian (Liu H. et al., 2014) PAs, where orchids are mostly considered as medicinal plants. Other studies have confirmed the wide economic use of orchids in Asia, too (Bulpitt, 2005; Chauhan \& Chauhan, 2014; Kreziou et al., 2016).

On the basis of the review of quality of journals, no considerable differences in the number of journals with different quartiles in both Scopus and WoS CC databases could be found. This is an evidence for the wide diversity of studies on orchids in PAs with almost an equal number of journals per quartile. Among the 159 journals included in the review, there was only one title (Lankesteriana indexed in Scopus) focusing on the study of Orchidaceae. Noteworthy, of the total number of identified journals, Lankesteriana published almost the highest number of articles included in this review (Table). Despite its presence in the $3^{\text {rd }}$ quartile of Scopus and its high value for orchid taxonomy and conservation, this title is still not included in WoS CC (Karremans, 2016). Among the 17 distinguished leading journals, six of them (Phytotaxa, Lankesteriana, Turczaninowia, PhytoKeys, Plant Systematics and Evolution, Taiwania) predominantly publish taxonomic studies, two journals (Biodiversity and Conservation, Biological Conservation) focus on nature conservation studies. Other journals publish studies on botany, ecology and distribution of plants, including orchids. Thus, the whole list of journals includes titles predominantly dealing with taxonomy and conservation of orchids.

In this systematic review the utility of systematic reviews in both indicating and filling gaps in the literature on orchids in PAs has been shown. However, even if a review is based on national and international databases, it is not always possible to identify a range of the most important and comprehensive studies, particularly related to Orchidaceae species in PAs. Obviously, there is a need to include a higher number of related studies in some regions (e.g. Northern Asia, Africa, northern part of North America). It is urgent to fill large gaps in the knowledge on Orchida- ceae in PAs. To obtain a full picture of studies on orchids in PAs, we suggest taking into account studies of orchids in temperate PAs in a higher number of non-English-language literature and a wider range of scientific regional and national databases. These actions will potentially broaden the knowledge and understanding of orchid biodiversity and conservation worldwide.

\section{Conclusions}

Despite the undoubted significance of international (Web of Science Core Collection and Scopus) and national (Russian Science Citation Index) databases to search and accumulate the most important data, the use of only these sources is not sufficient to generalise full comprehensive data about Orchidaceae worldwide. It especially concerns the regions outside the tropics and subtropics where there are numerous taxonomic, distributional, and populations-based studies. A large portion of valuable data on distribution, population status, and economic importance of orchids in PAs is obviously stored in national, non-English, databases. Proposed is the necessity to use additionally other, in English or non-English-language, national and regional databases to conduct the most comprehensive systematic reviews on Orchidaceae within and outside PAs.

\section{Acknowledgements}

I am grateful to two anonymous reviewers for their constructive comments and feedback on an earlier version of this paper. I am indebted to Wenbo Chen (Melbourne, Australia), Mihai Bobocea (Bucharest, Romania), Gennadiy G. Chugunov (Saransk, Russia), Petr G. Efimov (Saint-Petersburg, Russia) for providing the high-quality in-nature photographs.

\section{Supporting Information}

Bibliography of included publications on orchids in Protected Areas (Electronic Supplement 1: Bibliography of included papers on orchids in Protected Areas on the basis of data from Web of Science Core Collection, Scopus, and Russian Science Citation Index), and data on the analysed Protected Areas (Electronic Supplement 2: Characteristics of Protected Areas analysed in the present study) may be found in the Supporting Information here.

\section{References}

Acharya K.P., Vetaas O.R., Birks H.J.B. 2011. Orchid species richness along Himalayan elevational gradients. Journal of Biogeography 38(9): 1821-1833. DOI: 10.1111/j.1365-2699.2011.02511.x 
Akasaka M., Kadoya T., Ishihama F., Fujita T., Fuller R.A. 2017. Smart Protected Area Placement Decelerates Biodiversity Loss: A Representation-extinction Feedback Leads Rare Species to Extinction. Conservation Letters 10(5): 539-546. DOI: 10.1111/conl.12302

Averyanov L.V. 2012. New orchid taxa and records in the flora of Vietnam. Taiwania 57(2): 127-152. DOI: 10.6165/ tai.2012.57(2).127

Averyanov L.V., Vuong T.B., Tam T.Q. 2016a. The genus Liparis (Orchidaceae) in Hon Ba Nature Reserve, Vietnam, Khanh Hoa province. Turczaninowia 19(2): 34 49. DOI: 10.14258/turczaninowia.19.2.4

Averyanov L.V., Nguyen Kh.S., Maisak T.V., Konstantinov E.L.V., Nguyen T.H., Bounphanmy S. 2016b. New and rare orchids (Orchidaceae) in the flora of Cambodia and Laos. Turczaninowia 19(3): 5-58. DOI: 10.14258/turczaninowia.19.3.1

Averyanov L.V., Nuraliev M.S., Kuznetsov A.N., Kuznetsova S.P. 2018. Biermannia longicheila (Orchidaceae, Aeridinae), a new species from southern Vietnam. Phytotaxa 343(2): 194-198. DOI: 10.11646/phytotaxa.343.2.11

Barberena F.F.V.A., Baumgratz J.F.A., de Barros F. 2018. Ecological data for an orchid diversity hotspot show that the subtribe Laeliinae may be endangered in the Brazilian Atlantic Forest. Nordic Journal of Botany 36(7): e01728. DOI: 10.1111/njb.01728

Beshko N.Yu., Sharipova V.K., Shomurodov H.F. 2017: Floristic findings on the Nuratau and Zeravschan mountain ridges (Uzbekistan). Turczaninowia 20(3): 20-26. DOI: 10.14258/turczaninowia.20.3.3

Bicknell J.E., Collins M.B., Pickles R.S.A., McCann N.P., Bernard C.R., Fernandes D.J., Miller M.G.R., James S.M., William A.U., Struebig M.J., Davies Z.G., Smith R.J. 2017. Designing protected area networks that translate international conservation commitments into national action. Biological Conservation 214: 168-175. DOI: 10.1016/j.biocon.2017.08.024

Blinova I.V., Uotila P. 2011. Chamorchis alpina and Epipactis helleborine in the Murmansk Region, Russia, and assessments of the orchids in the Region using the IUCN Red List Categories. Memoranda Soc. Fauna Flora Fennica 87: 21-28.

Brzosko E., Ostrowiecka B., Kotowicz J., Bolesta M., Gromotowicz A., Gromotowicz M., Orzechowska A., Orzołek J., Wojdalska M. 2017. Seed dispersal in six species of terrestrial orchids in Biebrza National Park (NE Poland). Acta Societatis Botanicorum Poloniae 86(3): 3557. DOI: 10.5586/asbp.3557

Bulafu C.E., Mucunguzi P., Kakudidi E.K. 2007. Diversity and distribution of wild terrestrial orchids of Mt Elgon Forest National Park, eastern Uganda. African Journal of Ecology 45(Suppl. 3): 21-28. DOI: 10.1111/j.13652028.2007.00852.x

Bulpitt C.J. 2005. The uses and misuses of orchids in medicine. QJM: An International Journal of Medicine 98(9): 625-631. DOI: 10.1093/qjmed/hci094

Butchart S.H.M., Walpole M., Collen B., van Strien A., Scharlemann J.P.W., Almond R.E.A., Baillie J.E.M., Bomhard B., Brown C., Bruno J., Carpenter K.E., Carr
G.M., Chanson J., Chenery A.M., Csirke J., Davidson N.C., Dentener F., Foster M., Galli A., Galloway J.N., Genovesi P., Gregory R.D., Hockings M., Kapos V., Lamarque J.F., Leverington F., Loh J., McGeoch M.A., McRae L., Minasyan A., Hernández Morcillo M., Oldfield T.E.E., Pauly D., Quader S., Revenga C., Sauer J.R., Skolnik B., Spear D., Stanwell-Smith D., Stuart S.N., Symes A., Tierney M., Tyrrell T.D., Vié J.C., Watson R. 2010. Global Biodiversity: Indicators of Recent Declines. Science 328(5982): 1164-1168. DOI: 10.1126/science. 1187512

Cerda C., Ponce A., Zappi M. 2013. Using choice experiments to understand public demand for the conservation of nature: A case study in a protected area of Chile. Journal for Nature Conservation 21(3): 143-153. DOI: 10.1016/j.jnc.2012.11.010

Chape S., Harrison J., Spalding M., Lysenko I. 2005. Measuring the extent and effectiveness of protected areas as an indicator for meeting global biodiversity targets. Philosophical Transactions of the Royal Society B: Biological Sciences 360(1454): 443-455. DOI: 10.1098/ rstb.2004.1592

Chase M.W. 2005. Classification of Orchidaceae in the age of DNA data. Curtis's Botanical Magazine 22(1): 2-7. DOI: $10.1111 /$ j.1355-4905.2005.00466.x

Chauhan S., Chauhan S.V.S. 2014. Medicinal importance of orchids-A review. Medicinal Plants - International Journal of Phytomedicines and Related Industries 6(1): 1-12. DOI: 10.5958/j.0975-6892.6.1.001

Chichorro F., Juslén A., Cardoso P. 2019. A review of the relation between species traits and extinction risk. Biological Conservation 237: 220-229. DOI: 10.1016/j. biocon.2019.07.001

Christenhusz M.J.M., Byng J.W. 2016. The number of known plant species in the world and its annual increase. Phytotaxa 261(3): 201-217. DOI: 10.11646/ phytotaxa.261.3.1

Clark N.E., Boakes E.H., McGowan P.J.K., Mace G.M., Fuller R.A. 2013. Protected Areas in South Asia Have Not Prevented Habitat Loss: A Study Using Historical Models of Land-Use Change. PLoS ONE 8(5): e65298. DOI: 10.1371/journal.pone.0065298

Coetzee B.W., Gaston K.J., Chown S.L. 2014. Local scale comparisons of biodiversity as a test for global protected area ecological performance: a meta-analysis. PLoS ONE 9: e105824. DOI: 10.1371/journal.pone.0105824

Conroy M.J., Runge M.C., Nichols J.D., Stodola K.W., Cooper R.J. 2011. Conservation in the face of climate change: The roles of alternative models, monitoring, and adaptation in confronting and reducing uncertainty. Biological Conservation 144(4): 1204-1213. DOI: 10.1016/j.biocon.2010.10.019

Crain B.J., Tremblay R.L. 2014. Do richness and rarity hotspots really matter for orchid conservation in light of anticipated habitat loss? Diversity and Distributions 20(6): 652-662. DOI: 10.1111/ddi.12179

Cribb P.J., Kell S.P., Dixon K.W., Barrett R.L. 2003. Orchid conservation: a global perspective. In: K.W. Dixon, S.P. Kell, R.L. Barrett, P.J. Cribb (Eds.): Orchid Conserva- 
tion. Kota Kinabalu, Sabah: Natural History Publications. P. 1-24.

Davis N.E., Bennett A., Forsyth D.M., Bowman D.M.J.S., Lefroy E.C., Wood S.W., Woolnough A.P., West P., Hampton J.O., Johnson C.N. 2016. A systematic review of the impacts and management of introduced deer (family Cervidae) in Australia. Wildlife Research 43(6): 515-532. DOI: 10.1071/WR16148

Descourvières P., Dubuisson J.-Y., Droissart V., Cribb P., Cawoy V., Simo-Droissart M., Sonké B., Stévart T. 2013. Rhipidoglossum montealenense (Orchidaceae), a new species from Equatorial Guinea and Cameroon. Plant Ecology and Evolution 146(3): 389-394. DOI: 10.5091/plecevo.2013.841

Dey S., Lahkar B.P., Das J.P., Nath N.K., Brahma N. 2007. Orchid diversity in Manas National Park, Assam. Journal of the Orchid Society of India 21(1-2): 65-68.

Droissart V., Cribb P.J., Simo-Droissart M., Stévart T. 2014. Taxonomy of Atlantic Central African orchids 2. A second species of the rare genus Distylodon (Orchidaceae, Angraecinae) collected in Cameroon. PhytoKeys 2014(36): 27-34. DOI: 10.3897/phytokeys.36.7225

Dudley N. (Ed.). 2008. Guidelines for Applying Protected Area Management Categories. Gland, Switzerland: IUCN. 86 p.

Dutra D., Kane M.E., Adams C.R., Richardson L. 2009. Reproductive biology of Cyrtopodium punctatum in situ: Implications for conservation of an endangered Florida orchid. Plant Species Biology 24(2): 92-103. DOI: 10.1111/j.1442-1984.2009.00242.x

Efimov P.G. 2020. Orchids of Russia: annotated checklist and geographic distribution. Nature Conservation Research 5(Suppl.1): 1-18. DOI: 10.24189/ncr.2020.018

Eliáš P., Dítě D., Kliment J., Hrivnák R., Feráková V. 2015. Red list of ferns and flowering plants of Slovakia, $5^{\text {th }}$ edition (October 2014). Biologia 70(2): 218-228.

Fateryga A.V., Popovich A.V., Fateryga V.V., Kreutz C.A.J. 2020. Cephalanthera epipactoides (Orchidaceae) in Russia. Nature Conservation Research 5(Suppl.1): 69-76. DOI: $10.24189 /$ ncr.2020.014

Fitzsimons J. 2015. Private protected areas in Australia: current status and future directions. Nature Conservation 10: 1-23. DOI: 10.3897/natureconservation.10.8739

Forster W., Souza V.C. 2007. Epidendrum caparaoense (Orchidaceae), a new species from Minas Gerais, Brazil. Botanical Journal of the Linnean Society 155(1): 157159. DOI: 10.1111/j.1095-8339.2007.00630.x

Furlonge T., Dyer F., Davis J. 2015. The influence of differing protected area status and environmental factors on the macroinvertebrate fauna of temperate austral wetlands. Global Ecology and Conservation 4: 277-290. DOI: 10.1016/j.gecco.2015.07.007

Gale S.W., Kumar P., Li J., Hu A.Q., Zhang H., Yang P.F., Fischer G. 2013. Delivering species- and habitat-specific conservation strategies for Indo-Burma's Threatened Orchids. In: Proceedings of the 11th Asia Pacific Orchid Conference. Okinawa. P. 32-35.

Gale S.W., Fischer G.A., Cribb P.J., Fay M.F. 2018. Orchid conservation: bridging the gap between science and practice. Botanical Journal of the Linnean Society 186(4): 425-434. DOI: 10.1093/botlinnean/boy003

Galvin K.A., Beeton T.A., Luizza M.W. 2018. African community-based conservation: a systematic review of social and ecological outcomes. Ecology and Society 23(3): 39. DOI: 10.5751/ES-10217-230339

Gaston K.J., Jackson S.F., Nagy A., Cantú-Salazar L., Johnson M. 2008. Protected Areas in Europe. Principles and practice. Annals of the New York Academy of Sciences 1134(1): 97-119. DOI: 10.1196/annals.1439.006

Gebremedihin K.M., Birhane E., Tadesse T., Gbrewahid H. 2018. Restoration of degraded drylands through exclosures enhancing woody species diversity and soil nutrients in the highlands of Tigray, Northern Ethiopia. Nature Conservation Research 3(1): 1-20. DOI: 10.24189/ncr.2018.001

Geldmann J., Barnes M., Coad L., Craigie I.D., Hockings M., Burgess N.D. 2013. Effectiveness of terrestrial protected areas in reducing habitat loss and population declines. Biological Conservation 161: 230 -238. DOI: 10.1016/j.biocon.2013.02.018

Givnish T.J., Spalink D., Ames M., Lyon S.P., Hunter S.J., Zuluaga A., Doucette A., Caro G.G., McDaniel J., Clements M.A., Kalin Arroyo M.T., Endara L., Kriebel R., Williams N.H., Cameron K.M. 2016. Orchid historical biogeography, diversification, Antarctica and the paradox of orchid dispersal. Journal of Biogeography 43(10): 1905-1916. DOI: 10.1111/jbi.12854

Gravendeel B., Smithson A., Slik F.J.W., Schuiteman A. 2004. Epiphytism and pollinator specialization: drivers for orchid diversity. Philosophical Transactions of the Royal Society B: Biological Sciences 359(1450): 1523 1535. DOI: $10.1098 /$ rstb.2004.1529

Gray C.L., Hill S.L.L., Newbold T., Hudson L.N., Borger L., Contu S., Hoskins A.J., Ferrier S., Purvis A., Scharlemann J.P.W. 2016. Local biodiversity is higher inside than outside terrestrial protected areas worldwide. Nature Communications 7: 12306. DOI: 10.1038/ncomms 12306

Gutting A., Zettler J.A., Zettler L.W., Richardson L.W. 2015. An Update on Mealybugs and Scale Insects (Hemiptera) on Native Epiphytic Orchids in South Florida, Including a New record for Pseudococcus microcirculus (Pseudococcidae). Florida Entomologist 98(2): 401-404. DOI: 10.1653/024.098.0201

Hervouet J.M., Misandeau C. 2018. The ongoing story of Ambodiriana forest in Madagascar, a representative case study of in situ conservation. In: $18^{\text {th }}$ European Orchid Council Conference and Exhibition "What future for orchids?" (Paris, March 23-25, 2018). Paris. P. 11-12.

Hill R., Miller C., Newell B., Dunlop M., Gordon I.J. 2015. Why biodiversity declines as protected areas increase: the effect of the power of governance regimes on sustainable landscapes. Sustainability Science 10(2): 357 369. DOI: $10.1007 / \mathrm{s} 11625-015-0288-6$

Hopper S.D., Gioia P. 2004. The Southwest Australian Floristic Region: evolution and conservation of a global diversity hotspot. Annual Review of Ecology, Evolution, and Systematics 35(1): 623-650. DOI: 10.1146/ annurev.ecolsys.35.112202.130201 
Huang B.Q., Yang X.Q., Yu F.H., Luo Y.B., Tai Y.D. 2008. Surprisingly high orchid diversity in travertine and forest areas in the Huanglong valley, China, and implications for conservation. Biodiversity and Conservation 17(1): 2773-2786. DOI: 10.1016/j.biocon.2014.10.026

Indsto J.O., Weston P.H., Clements M.A., Dyer A.G., Batley M., Whelan R.J. 2006. Pollination of Diuris maculata (Orchidaceae) by male Trichocolletes venustus bees. Australian Journal of Botany 54(7): 669-679. DOI: 10.1071/BT05146

Jackson S.F., Gaston K.J. 2008. Land use change and the dependence of national priority species on protected areas. Global Change Biology 14(9): 2132-2138. DOI: 10.1111/j.1365-2486.2008.01628.x

Jackson S.F., Walker K., Gaston K.J. 2009. Relationship between distributions of threatened plants and protected areas in Britain. Biological Conservation 142(7): 15151522. DOI: 10.1016/j.biocon.2009.02.020

Jacquemyn H., Micheneau C., Roberts D.L., Pailler T. 2005. Elevational gradients of species diversity, breeding system and floral traits of orchid species on Réunion Island. Journal of Biogeography 32(10): 1751-1761. DOI: $10.1111 /$ j.1365-2699.2005.01307.x

Jagiełło M. 1988. A new natural intergeneric hybrid $-\times$ Dactylodenia vitosensis (Orchidaceae). Folia Geobotanica et Phytotaxonomica 23(1): 95-97. DOI: 10.1007/BF02853298

Ječmenica V., Droissart V., Noret N., Stévart T. 2016. Taxonomy of Atlantic central African orchids 5. A new species of Angraecum sect. Conchoglossum (Orchidaceae, Angraecinae) from Gabon and Cameroon. PhytoKeys 61(1): 61-71. DOI: 10.3897/phytokeys.61.7017

Ječmenica V., Droissart V., Akouangou E., Nyangala C., Bakita B., Biteau J.P., Stévart T. 2017. Taxonomy of Atlantic central African orchids, 6: Three new species of Angraecum sect. Afrangraecum (Orchidaceae, Angraecinae) from Gabon and São Tomé. Phytotaxa 323(2): 143-158. DOI: 10.11646/phytotaxa.323.2.3

Jones C.A., Daehler C.C. 2018. Herbarium specimens can reveal impacts of climate change on plant phenology; a review of methods and applications. PeerJ 6: e4576. DOI: $10.7717 /$ peerj. 4576

Karremans A.P. 2016. Lankesteriana, a no impact journal... or is it? Lankesteriana 16(1): 53-55.

Khapugin A.A., Korochkina A.M. 2017. Population-based study of Platanthera bifolia in the Mordovia State Nature Reserve (Republic of Mordovia, Central Russia). Orchidee Spontanee d'Europa - European Native Orchids 60(2): 276-294.

Khapugin A.A., Chugunov G.G., Silaeva T.B., Kunaeva E.N. 2016. Neottianthe cucullata (L.) Schltr. (Orchidaceae Juss.), an endangered orchid in Central Russia. Wulfenia 23: 189-202.

Khapugin A.A., Chugunov G.G., Vargot E.V. 2017a. Cypripedium calceolus (Orchidaceae) in central Russia: A case study for its populations in two protected areas in the Republic Of Mordovia (Russia). Lankesteriana 17(3): 417-431. DOI: 10.15517/lank.v17i3.31577
Khapugin A.A., Silaeva T.B., Vargot E.V., Chugunov G.G., Grishutkina G.A., Grishutkin O.G., Pismarkina E.V., Orlova Ju.S. 2017b. Estimation of taxa included in the first volume of the Red Data Book of the Republic of Mordovia (Russia) using the IUCN Red List Categories and Criteria. Nature Conservation Research 2(Suppl.1): 164-189. DOI: 10.24189/ncr.2017.004

Kirillova I.A., Kirillov D.V. 2020. Impact of weather conditions on seasonal development, population structure and reproductive success on Dactylorhiza traunsteineri (Orchidaceae) in the Komi Republic (Russia). Nature Conservation Research 5(Suppl.1): 77-89. DOI: 10.24189/ncr.2020.016

Koval L.V., Horshkova L.M., Kuzmenko L.O., Mehem O.M., Burchak L.V., Polyakova A.S. 2018. Sozological peculiarities of the flora of the Desna Plateau (Ukraine). Biosystems Diversity 26(1): 37-45. DOI: 10.15421/011806

Kreutz C.A.J., Kreutz K., Fateryga A.V., Ivanov S.P. 2018. Orchids of the Crimea: Description, Pattern of Life, Distribution, Threats, Conservation, Iconography. Engels: Kreutz-Publishers. 576 p.

Kreziou A., De Boer H., Gravendeel B. 2016. Harvesting of salep orchids in north-western Greece continues to threaten natural populations. Oryx 50(3): 393-396. DOI: $10.1017 / \mathrm{S} 0030605315000265$

Kull T., Selgis U., Peciña M.V., Metsare M., Ilves A., Tali K., Sepp K., Kull K., Shefferson R.P. 2016. Factors influencing IUCN threat levels to orchids across Europe on the basis of national red lists. Ecology and Evolution 6(17): 6245-6265. DOI: 10.1002/ece3.2363

Le Roux J.J., Hui C., Castillo M.L., Iriondo J.M., Keet J.H., Khapugin A.A., Médail F., Rejmánek M., Theron G., Yannelli F.A., Hirsch H. 2019. Recent Anthropogenic Plant Extinctions Differ in Biodiversity Hotspots and Coldspots. Current Biology 29(17): 2912-2918. DOI: 10.1016/j.cub.2019.07.063

Lemenager T., King D., Elliott J., Gibbons H., King A. 2014. Greater than the sum of their parts: Exploring the environmental complementarity of state, private and community protected areas. Global Ecology and Conservation 2: 238-247. DOI: 10.1016/j.gecco.2014.09.009

Leroux S.J., Brimacombe C., Khair S., Benidickson J., Findlay C.S. 2015. Legislative correlates of the size and number of protected areas in Canadian jurisdictions. Biological Conservation 191: 375-382. DOI: 10.1016/j.biocon.2015.07.016

Leverington F., Costa K.L., Pavese H., Lisle A., Hockings M. 2010. A Global Analysis of Protected Area Management Effectiveness. Environmental Management 46(5): 685-698. DOI: 10.1007/s00267-010-9564-5

Liu H., Feng C.L., Luo Y.B., Chen B.S., Wang Z.S., Gu H.Y. 2010. Potential challenges of climate change to orchid conservation in a Wild Orchid Hotspot in Southwestern China. Botanical Review 76(2): 174-192. DOI: 10.1007/s12229-010-9044-X

Liu H., Luo Y.B., Heinen J., Bhat M., Liu Z.J. 2014. Eat your orchid and have it too: A potentially new conservation formula for Chinese epiphytic medicinal orchids. Biodiversity and Conservation 23(5): 1215-1228. DOI: 10.1007/s10531-014-0661-2 
Liu Q., Chen J., Corlett R.T., Fan X., Yu D., Yang H., Gao J. 2015. Orchid conservation in the biodiversity hotspot of southwestern China. Conservation Biology 29(6): 1563-1572. DOI: $10.1111 /$ cobi. 12584

Lowry E., Rollinson E.J., Laybourn A.J., Scott T.E., Aiello-Lammens M.E., Gray S.M., Mickley J., Gurevitch J. 2013. Biological invasions: a field synopsis, systematic review, and database of the literature. Ecology and Evolution 3(1): 182-196. DOI: 10.1002/ece3.431

McCormick M.K., Jacquemyn H. 2014. What constrains the distribution of orchid populations? New Phytologist 202(2): 392-400. DOI: 10.1111/nph.12639

Mucunguzi P. 2007. Diversity and distribution of vascular epiphytes in the forest lower canopy in Kibale National Park, western Uganda. African Journal of Ecology 45(Suppl.3): 120-125. DOI: 10.1111/j.13652028.2007.00868.x

Mújica E.B., Mably J.J., Skarha S.M., Corey L.L., Richardson L.W., Danaher M.W., González E.H., Zettler L.W. 2018. A comparison of ghost orchid (Dendrophylax lindenii) habitats in Florida and Cuba, with particular reference to seedling recruitment and mycorrhizal fungi. Botanical Journal of the Linnean Society 186(4): 572-586. DOI: 10.1093/botlinnean/box106

Myers N., Mittermeier R.A., Mittermeier C.G., da Fonseca G.A.B., Kent J. 2000. Biodiversity hotspots for conservation priorities. Nature 403: 853-858. DOI: $10.1038 / 35002501$

PARF. 2019. The information-analytical system «Protected Areas of Russia» (database). Available from http://oopt. aari.ru [In Russian]

Pelser P.B., Doble K.J.S., O’Byrne P., Ormerod P., Barcelona J.F. 2016. Gastrodia cajanoae (Orchidaceae: Epidendroideae: Gastrodieae), a new species from the Philippines. Phytotaxa 266(1): 53-56. DOI: 10.11646/phytotaxa.266.1.9

Pierce S., Ceriani R.M., Villa M., Cerabolini B. 2006. Quantifying relative extinction risks and targeting intervention for the orchid flora of a natural park in the European prealps. Conservation Biology 20(6): 1804-1810. DOI: $10.1111 / \mathrm{j} .1523-1739.2006 .00539 . \mathrm{x}$

Puchnina L.V. 2017. Status of Calypso bulbosa and Cypripedium calceolus (Orchidaceae) populations in the Pinega State Nature Reserve. Nature Conservation Research 2(Suppl.1): 125-150. DOI: 10.24189/ncr.2017.023

Raventós J., González E., Mújica E., Doak D.F. 2015. Population Viability Analysis of the Epiphytic Ghost Orchid (Dendrophylax lindenii) in Cuba. Biotropica 47(2): 179-189. DOI: 10.1111/btp.12202

Reiter N., Clements M., Vlcek K. 2013. An examination of Pterostylis xerophila (Orchidaceae) and the confirmation of $P$. lingua as a new species in Victoria. Muelleria 31(1): 69-76.

Samant S.S., Dhar U., Rawal R.S. 1998. Biodiversity status of a protected area in West Himalaya: Askot Wildlife Sanctuary. International Journal of Sustainable Development and World Ecology 5(3): 194-203. DOI: 10.1080/13504509809469983
Schödelbauerová I., Roberts D.L., Kindlmann P. 2009. Size of protected areas is the main determinant of species diversity in orchids. Biological Conservation 142(10): 2329-2334. DOI: 10.1016/j.biocon.2009.05.015

Serra Laliga L., Albors J., González S., Hernández J.C., Llinares V., Llobregat L., Benavent J.O., Pedauyé H., Perales P., Peris J.I., Ortega E.P., Rodríguez J.A., Moñino A.S., Sanchis M.J., Sanz A., Soler J.X., Torregrosa R. 2015. Additions and corrections about valencian Orchidaceae, VI. Flora Montiberica 59: 41-51.

Simo-Droissart M., Stévart T., Sonké B., Mayogo S., Kamdem N., Droissart V. 2018. New taxonomic and conservation status of Ossiculum (Vandeae, Orchidaceae), a highly threatened and narrow-endemic angraecoid orchid from Central Africa. PhytoKeys 98: 85-97. DOI: 10.3897/phytokeys.98.23511

Sinu P.A., Kuriakose G., Chandrashekara K. 2011. Epiphytic orchid diversity in farmer-managed Soppinabetta forests of Western Ghats: implications for conservation. Current Science 101(10): 1337-1346.

Soto Arenas M.Á., Gómez R.S., Hágsater E. 2007. Risk of extinction and patterns of diversity loss in Mexican orchids. Lankesteriana 7(1-2): 114-121.

Stefaniak A., Ziemkiewicz S., Karczewska M., Klejps A., Jakubska-Busse A. 2013. The current condition of the Orchidaceae populations in Polish national parks. Archives of Biological Sciences 65(3): 1079-1086. DOI: 10.2298/ABS1303079S

Swarts N.D., Dixon K.W. 2009. Terrestrial orchid conservation in the age of extinction. Annals of Botany 104(3): 543-556. DOI: 10.1093/aob/mcp025

Talalaj I., Ostrowiecka B., Wlostowska E., Rutkowska A., Brzosko E. 2017. The ability of spontaneous autogamy in four orchid species: Cephalanthera rubra, Neottia ovata, Gymnadenia conopsea, and Platanthera bifolia. Acta Biologica Cracoviensia. Series Botanica 59(2): 51-61. DOI: 10.1515/abcsb-2017-0006

Tsiftsis S., Tsiripidis I. 2015. Orchids of Northern Pindos National Park. Aspraggeloi; Ioannina: Management Agency of Vikos-Aoos and Pindos National Forests. 204 p.

Tuvi E.L., Vellak A., Reier U., Szava-Kovats R., Partel M. 2011. Establishment of protected areas in different ecoregions, ecosystems, and diversity hotspots under successive political systems. Biological Conservation 144(5): 1726-1732. DOI: 10.1016/j.biocon.2011.03.008

UNEP-WCMC \& IUCN. 2019. Protected Planet: The World Database on Protected Areas (WDPA) [On-line], December 2019. Cambridge, UK: UNEP-WCMC. Available from: www.protectedplanet.net

Vakhrameeva M.G., Varlygina T.I., Tatarenko I.V. 2014. Orchids of Russia (Biology, Ecology, Conservation). Moscow: KMK Scientific Press Ltd. 437 p.

Vellak A., Tuvi E.L., Reier U., Kalamees R., Roosaluste E., Zobel M., Pärtel M. 2009. Past and Present Effectiveness of Protected Areas for Conservation of Naturally and Anthropogenically Rare Plant Species. Conservation Biology 23(3): 750-757. DOI: 10.1111/j.1523-1739.2008.01127.x

Waterman R.J., Bidartondo M.I. 2008. Deception above, deception below: linking pollination and mycorrhizal 
biology of orchids. Journal of Experimental Botany 59(5): 1085-1096. DOI: 10.1093/jxb/erm366

Wraith J., Pickering C. 2017. Tourism and recreation a global threat to orchids. Biodiversity and Conservation 26(14): 3407-3420. DOI: 10.1007/s10531-017-1412-y

Zhang Z., Yan Y., Tian Y., Li J., He J.S., Tang Z. 2015. Distribution and conservation of orchid species richness in China. Biological Conservation 181: 64-72. DOI: 10.1016/j.biocon.2014.10.026

Zhou S.S., Tan Y.H., Jin X.H., Maung K.W., Zyaw M., Li R., Quan R.C., Liu Q. 2018. Coelogyne victoria-reginae (Orchidaceae, Epidendroideae, Arethuseae), a new species from Chin State, Myanmar. PhytoKeys 98: 125133. DOI: $10.3897 /$ phytokeys.98.23298

\title{
ГЛОБАЛЬНЫЙ ЛИТЕРАТУРНЫЙ ОБЗОР ДАННЫХ ОБ ОРХИДЕЯХ НА ОСОБО ОХРАНЯЕМЫХ ПРИРОДНЫХ ТЕРРИТОРИЯХ
}

\author{
А. А. Хапугин ${ }^{1,2}$ \\ ${ }^{1}$ Объединенная дирекция Мордовского государственного природного заповедника \\ имени П.Г. Смидовича и национального парка «Смольный», Россия \\ ${ }^{2}$ Тюменский государственный университет, Россия \\ e-mail: hapugin88@yandex.ru
}

Данная статья представляет собой обзор мировой литературы, посвященный изучению видов семейства Orchidaceae на особо охраняемых природных территориях (ООПТ). Работа направлена на понимание направлений исследований орхидей на ООПТ по всему миру. Мы использовали методологию, хорошо зарекомендовавшую себя в биологических и медицинских науках, с акцентом на две международные и одну национальную базы данных (Scopus, Web of Science Core Collection, РИНЦ). Нами были изучены данные о местонахождении каждой ООПТ, исследованного биотопа и обсуждаемой тематике исследования с учетом категории ООПТ по классификации МСОП. Мы предположили, что орхидеи преимущественно исследуются на ООПТ, и поэтому опубликованные результаты этих исследований должным образом проиндексированы библиографическими базами данных во всем мире. Мы проверили, будут ли такие наиболее угрожаемые и одни из самых изучаемых растений, как орхидеи, детально и интенсивно исследованы на законодательно охраняемых территориях (природные заповедники, национальные парки, памятники природы, заказники дикой природы и т.д.)? А также охватывают ли базы данных Scopus, Web of Science Core Collection, РИНЦ большинство публикаций, посвященных орхидеям на ООПТ в глобальном масштабе. Нами выявлена 331 публикация, посвященная орхидным на ООПТ, в том числе 72 публикации из базы данных РИНЦ, 96 - из базы данных Scopus, 163 - из базы данных Web of Science Core Collection. Большая часть исследований была проведена в тропиках, в то время как крупные регионы умеренной и субтропической зон (Северная Евразия, Центральная и Западная Азия, Северная и Центральная части Северной Америки, внетропическая Африка, большая часть Австралии) были слабо представлены публикациями в анализируемых базах данных. Большинство исследований было проведено в лесах (по убыванию числа публикаций - тропических, умеренной зоны, таежных). Они были посвящены преимущественно распространению и разнообразию орхидных на ООПТ. Меньшее количество исследований было посвящено таксономии, структуре и динамике популяций, угрозе исчезновений орхидных, а также взаимодействиям орхидных с другими организмами (насекомыми-опылителями, деревьями-форофитами, грибами-симбионтами). Мы также пришли к выводу, что использование только баз данных Scopus, Web of Science Core Collection, РИНЦ не может предоставить достаточного количества данных для всестороннего обобщения данных об исследованиях орхидей на ООПТ в глобальном масштабе. Для будущих систематических обзоров предлагается использовать другие, не только англоязычные, международные и национальные базы данных, насколько это возможно.

Ключевые слова: Orchidaceae библиографическая база данных, биоразнообразие, заповедник, местообитание, национальный парк, сохранение природы, угрожаемые таксоны, фокус исследования 